NSF director backs environment studies

[WASHINGTON] The National Science Foundation (NSF) is planning a major environmental science initiative that will satisfy pressure from some Congressmen for it to accommodate a 'national institute for the environment' (NIE), while reflecting the interests of Rita Colwell, the marine biologist who was sworn in last month as the foundation's new director.

Earlier this year, the National Science Board, which overseas the NSF, asked Jane Lubchenco of Oregon State University to chair a task force on the environment that will report back early in 1999 . The board also emphatically rejected the NIE proposal, saying it "would create an additional and wasteful structure and bureaucracy where no such need exists".

Now Colwell, a former proponent of an NIE, predicts that the study will lead to a new initiative in environmental research. "We are now beginning to invest in the early stages of a biocomplexity/ecosystem dynamics initiative, and we are addressing this in a very serious way," she said in an interview.

Colwell was a member of the board of directors of the Committee for the National Institute of the Environment, which has been campaigning in Washington for several years to create a new federal agency to perform environmental research. She resigned from the board in February, when she was named by President Bill Clinton to head the NSF. But she denies having changed her position on the need for such an agency. "The call was for increased research in the environment," she says. "I was never a proponent of a separate, independent agency, but I remain an ardent proponent of more environmental research."

Colwell says that her priorities for the agency, which funds most non-biomedical

\title{
US drive to speed trials for rare disorders
}

[WASHINGTON] The US Food and Drug Administration (FDA) and the National Institutes of Health (NIH) are launching an initiative to make clinical trials for rare illnesses speedier, less cumbersome and less costly.

The FDA and NIH aim to promote research on gene therapies for rare disorders by luring more investigators into the area and encouraging industry to support research in clinical areas that do not have a big market.

The NIH has received 259 applications for gene therapy protocols in the past ten years. But few involve rare diseases, even though gene therapy was conceived to treat rare, inherited disorders due to mutations in a single gene. These 'monogenic' diseases are increasingly ignored as scientists and their industry sponsors focus on developing gene therapies for large-market diseases such as AIDS and cancer.

Only 34 protocols have been for monogenic diseases. By contrast, 61 per cent have been for cancer. And the trend is growing

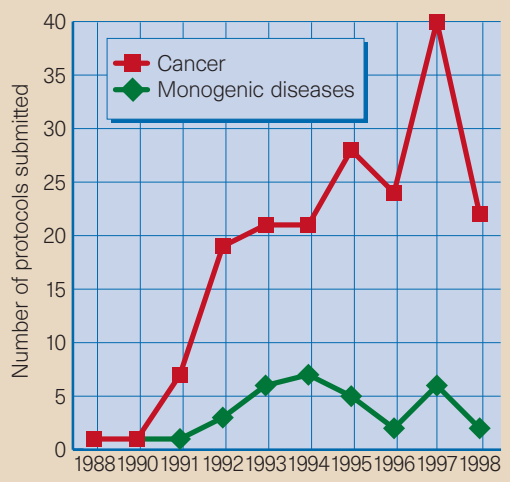

Protocols submitted to the NIH Recombinant DNA Advisory Committee, 1988-98. more marked. Of 31 protocols submitted so far in 1998, two are for monogenic diseases while 22 are for cancer.

"All the money is going into the most profitable diseases... so it's obviously an area that the government has to step into," says Abbey Meyers, the president of the National Organization for Rare Disorders.

Philip Noguchi, the director of FDA's Division of Cellular and Gene Therapies, says gene therapy's "focus [on rare diseases] has drifted over the last few years. This [new initiative] is an attempt to bring it back."

A working group from the FDA's Center for Biologics Evaluation and Research and the NIH's Office of Rare Diseases is developing a strategy to speed up trials.

First, it wants to relieve investigators of the need to reinvent the wheel each time they apply to do a gene therapy experiment. Currently, each investigator must prove a given vector is safe for a proposed therapy. The group hopes to demonstrate through NIHfunded studies that a particular vector is broadly safe so investigators will not have to demonstrate its safety separately.

Second, the group proposes that the FDA accepts protocols with as few patients as possible and merges safety and efficacy studies, which are conducted in separate stages.

Even if the initiative greatly reduces the early development costs for companies, however, there remains little incentive to commercialize for small target populations. James Wilson, the director of the Institute for Human Gene Therapy at the University of Pennsylvania, says he is "afraid we will still be left with some diseases in which we can't encourage anybody to do it". Meredith Wadman

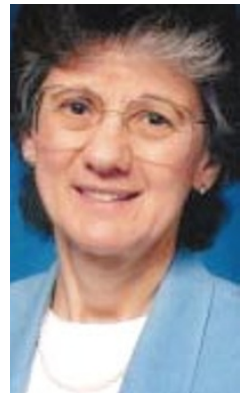

university research in the United States, would include interdisciplinary research, science education and international scientific collaboration.

She says she wants the NSF to be at the forefront of advanced computing research. Last week she met Ernest Colwell: outlining Moniz, the underagency's priorities. secretary of energy, to discuss possible NSF involvement in Moniz's plan for a major supercomputing initiative at the Department of Energy's non-weapons laboratories (see Nature 390, 651; 1997).

Energy department sources and Colwell say that the initiative is likely to be in the Clinton administration's budget request for the year 2000 as a multi-agency initiative involving the Department of Energy, the NSF, the National Institutes of Health and other science agencies.

Colwell says the NSF - which is administratively divided into directorates and divisions that address specific scientific disciplines - is already improving its mechanisms for supporting interdisciplinary work. She points, for example, to its recent establishment of an office of integrated activities, which has a dozen staff. The office is "an indication that we're moving in some new directions", she says. Pointing out that the NSF structure reflects the structure of the universities, which "is undergoing major change", Colwell declines to rule out a major reorganization of the agency. "I've only been here three weeks - I need time to work with the associate directors," she says.

Colwell, who was director of the multidisciplinary University of Maryland Biotechnology Institute at Baltimore, also defends her role in winning federal funds for the Christopher Columbus Center, a \$160 million research and education centre in Baltimore, whose public outreach activities have been temporarily shut down after running into financial difficulties. "Every single research project in that building has been peer-reviewed", she says. "The one part that hasn't done too well wasn't under my control at all. It is being reorganized and it will be a success."

She adds that the NSF is currently examining its own administrative needs, as its staff has been held at 1,200 for ten years while its budget has doubled to $\$ 3.5$ billion (see Nature 393, 100; 1998). "We're definitely looking into it. Joe [Bordogna, acting deputy director of NSF] has already initiated some studies on the organizational structure here."

ColinMacilwain 